\title{
Sequential bioprocessing of Ulva rigida to produce lignocellulolytic enzymes and to improve its nutritional value as aquaculture feed
}

\author{
Helena Fernandes, ${ }^{\mathrm{b}, \mathrm{c}}$, José Manuel Salgado ${ }^{\mathrm{a}, *}$, Nicole Martins ${ }^{\mathrm{b}, \mathrm{c}}$, Helena Peres ${ }^{\mathrm{b}, \mathrm{c}}$, \\ Aires Oliva-Teles ${ }^{c}$, Isabel Belo ${ }^{\mathrm{a}}$ \\ ${ }^{a}$ Centre of Biological Engineering, University of Minho, Campus de Gualtar, 4710-057 Braga, Portugal \\ ${ }^{\mathrm{b}}$ Interdisciplinary Centre of Marine and Environmental Research (CIIMAR), Portugal \\ ${ }^{\mathrm{c}}$ Department of Biology, Faculty of Sciences of University of Oporto (FCUP), Portugal
}

\section{A R T I C L E I N F O}

\section{Keywords:}

Ulva rigida

Solid-state fermentation

Enzymatic hydrolysis

Xylanase

Cellulase

\begin{abstract}
A B S T R A C T
The macroalgae aquaculture industry has grown up in the last years, and new applications for macroalgae should be considered. In this work, sequential biological treatments as solid-state fermentation (SSF) by Aspergillus ibericus and enzymatic hydrolysis (EH) were applied to washed and unwashed Ulva rigida. SSF of unwashed macroalgae showed higher xylanase $(359.8 \mathrm{U} / \mathrm{g})$, cellulase $(73.07 \mathrm{U} / \mathrm{g})$ and $\beta$-glucosidase $(14.9 \mathrm{U} / \mathrm{g})$ activities per dry mass of macroalgae. After SSF, two strategies to carry out EH were assayed. The best process was SSF followed by EH by simply adding a buffer. The non-starch polysaccharides content was reduced by $93.2 \%$, achieving a glucan conversion of $98 \%$. In addition, the antioxidant activity was improved 2.8 -fold and the protein concentration of macroalgae extracts increased from $16.9 \%$ to $29.8 \%$ (w/w). These biological treatments allowed to increase macroalgae value as feedstuff with potential for use in aquafeeds.
\end{abstract}

\section{Introduction}

Macroalgae are macroscopic algae with high growth rate (Ilias et al., 2015) and in the last two decades, world macroalgae production increased at a rate of $8.7 \%$ per year (FAO, 2018). The global annual value of macroalgae was estimated between US $\$ 10$ and US $\$ 16$ billions in 2012 (White and Wilson, 2015). Due to its high growth rate, minimal use of freshwater and arable land, macroalgae are a potential feedstock with several industrial applications (Chemodanov et al., 2017), although it remains largely underexploited.

The use of macroalgae and their wastes as feedstocks for biorefining technologies is encouraged by the European Agenda 2030 for the development of blue biorefinery, under circular economy with the ultimate goal of zero wastes (Manan and Webb, 2017)

Besides this potential use for biorefinery, macroalgae is also a good source of protein and bioactive compounds. Macroalgae may be refined into fractions, producing a range of bioactive compounds (Kostas et al., 2017), such as antioxidants, carotenoids, polyphenols, vitamins, minerals, and polyunsaturated fatty acids with nutritional, pharmaceutical, cosmetics, and agrichemicals applications (James et al., 2012). Macroalgae may also be used in the animal feed production, as feedstuff or as a source of functional additives (Miranda et al., 2017).
Green macroalgae (Chlorophyta) along with red macroalgae are the most promising algal groups for utilization in food and feed (Biancarosa et al., 2018). However, the use of macroalgae in animal feed and biofuel industry may be impaired by the non-starch polysaccharides (NSP) content, mainly cellulose and hemicellulose (Özçimen and İnan, 2015). NSP content are higher in green than in red or brown macroalgae (Karray et al., 2016) and it may limit macroalgae inclusion in animal feeds, as animals lack the digestive enzymes necessary to hydrolyse NSP, reducing nutrients and energy bioaccessibility (Mæhre et al., 2014). One the other hand, this high content of NSP, make macroalgae a good substrate for solid-sate fermentation (SSF).

Solid-State Fermentation (SSF) is a biotechnological process that recreates microbial natural conditions of growth, specifically of filamentous fungi (Soccol et al., 2017). SSF occurs with no free water using an inert or natural solid substrate. Marine biomass, as macroalgae, is a natural substrate that serves as both physical support and nutritional source, resulting in valuable feedstock for the production of enzymes, pharmaceutical, and cosmetic compounds, bioethanol and others (Manan and Webb, 2017). This technique usually produces more stable enzymes than those produced by submerged fermentation and allows the use of low-valued industrial by-products as SSF substrates (Farinas, 2015). Even thought, macroalgae are usually dried to be preserved, SSF

\footnotetext{
* Corresponding author.

E-mail address: jmsalgado@ceb.uminho.pt (J.M. Salgado).
} 
may use undried macroalgae as substrate to reduce the processing cost, but the scale-up of this process may be a challenge, due to the large amount of biomass.

Three types of cellulases are related to the hydrolysis of $\beta-1,4$ bonds and the release of glucose units from polymeric cellulose, endo-1-4- $\beta$ glucanase (EC 3.2.1.4), exoglucanase (EC 3.2.1.91) and $\beta$-glucosidase (EC 3.2.1.21). For hemicellulose degradation, different types of enzymes are involved, mainly endo-1,4- $\beta$-xylanase (EC 3.2.1.8) and xylan 1,4- $\beta$-xylosidase (EC 3.2.1.37).

These microbial enzymes are utterly important in diverse economic sectors, such as food, textile and paper industries (Raveendran et al., 2018). Manufacture of biofuels using lignocellulosic-rich agro-industrial residues (to produce cellulosic ethanol and biodiesel), promotion of bioremediation and biodegradation of dangerous compounds and acquisition of enhanced products that can be utilized in animal feed are some of the potentials advantages of the utilization of microbial enzymes (Farinas, 2015). Specifically, NSP enzymes are gaining more attention and represent a high-value income due its potential to improve digestibility of plant ingredients by degrading its cell walls components and reduce NSP's antinutritional effects (Castillo and Gatlin, 2015). This group of enzymes may be of special importance for the aquafeed industry, particularly in an era of novel aquafeeds formulations. In fact, aquaculture sector, has traditionally relied on fish meal and fish oil for diet formulation, particularly for carnivorous species (Tacon and Metian, 2015), but it nowadays faces an urgent need to reduce reliance upon fisheries ingredients (Ilias et al., 2015).

For aquaculture species, dietary supplementation with NSP degrading enzymes has been shown to improve digestibility of plant-based diets, thus improving dietary energy availability and reducing NSP's antinutritional effects (Castillo and Gatlin, 2015; Diógenes et al., 2018; Magalhães et al., 2016; Zhu et al., 2016). Therefore, application of NSP degrading enzymes to aquafeeds is gaining attention and may represent a high-value income.

There is a research gap regarding the potential of filamentous fungi growth on macroalgae and production of NSP degrading enzymes during the SSF process. Among filamentous fungi species used in SSF Aspergillus ibericus has been proved to be promising. It is "generally regarded as safe" (GRAS) (Oliveira et al., 2018), whose hyphal growth mode allows it to efficiently penetrate in the substrate, thus efficiently growing under SSF conditions, and it has potential to produce cellulases and xylanases (Salgado et al., 2014).

Therefore, this study aimed to perform SSF with A. ibericus as a biological pre-treatment of the macroalgae, $U$. rigida, and to evaluate the production of NSP degrading enzymes and antioxidant compounds with potential to be included in feeds for aquaculture fish species. Moreover, after SSF of $U$. rigida sequential enzymatic hydrolysis was tested to upgrade the nutritional value, in terms of increase the bioavailability of protein and antioxidant compounds and reduction of complex polysaccharide content. Pre-treated $U$. rigida and its enzymatic extracts and antioxidant compounds have high potential for application in the aquafeed industry.

\section{Materials and methods}

\subsection{Macroalgae and fungus}

Ulva rigida was provided by Algaplus, a company based in Aveiro, Portugal. Dry micronized U. rigida was used as is or washed, by immersion in distilled water $(1: 5 \mathrm{w} / \mathrm{v})$ for $48 \mathrm{~h}$, under constant agitation (150 rpm), vacuum filtrated and dried at $55{ }^{\circ} \mathrm{C}$ until constant weight. The fungus species used in SSF was Aspergillus ibericus (MUM 03.49) that was maintained in Potato Dextrose Agar, at $4{ }^{\circ} \mathrm{C}$ until utilization.

\subsection{Solid-state fermentation process}

U. rigida SSF was firstly performed at a laboratorial scale and then scaled up using tray type bioreactors.

SSF was performed in duplicate in $500 \mathrm{~mL}$ Erlenmeyer flasks with $10 \mathrm{~g}$ of dry unwashed or washed $U$. rigida without addition of nutritional supplements. The moisture level was adjusted to $75 \%$ followed by sterilization at $121{ }^{\circ} \mathrm{C}$ for $15 \mathrm{~min}$. Each Erlenmeyer flask was inoculated with $2 \mathrm{~mL}$ of spore suspension of $A$. ibericus following the method described by Sousa et al. (2018) and incubated at $25{ }^{\circ} \mathrm{C}$ for 7 days. The proximate composition of both unwashed or washed $U$. rigida was determined before and after SSF, and the enzymatic activity of the extracts after SSF.

The scale-up of SSF was performed in trays with $50 \mathrm{~g}$ and $400 \mathrm{~g}$ of macroalga without additional nutrients. Trays containing $50 \mathrm{~g}$ and $400 \mathrm{~g}$ measured $16 \times 11 \times 6 \mathrm{~cm}$ and $43 \times 33 \times 7 \mathrm{~cm}$, respectively. The height of SSF-bed in both trays dimensions measured $2,5 \mathrm{~cm}$. The moisture level was adjusted to $75 \%$ followed by sterilization at $121{ }^{\circ} \mathrm{C}$ for $15 \mathrm{~min}$. Each tray with $50 \mathrm{~g}$ and $400 \mathrm{~g}$ was inoculated with 10 and $80 \mathrm{~mL}$ of spore suspension of $A$. ibericus, respectively, and incubated at $25{ }^{\circ} \mathrm{C}$ for 7 days. The enzymatic activity of the extracts obtained after SSF were analyzed.

Another SSF was performed but without sterilization of the macroalga at $121{ }^{\circ} \mathrm{C}$ for $15 \mathrm{~min}$. Therefore, SSF of $50 \mathrm{~g}$ of dry $U$. rigida was placed in trays, in duplicate, and moisture level was adjusted to $75 \%$. Two trays were inoculated with $10 \mathrm{~mL}$ of spore suspension of $A$. ibericus while other two trays were not inoculated with this fungus but incubated, similarly, at $25{ }^{\circ} \mathrm{C}$ for 7 days. At the end of SSF, enzymatic activity of the extracts was analyzed.

\subsection{Fungal growth estimation}

Fungal biomass was estimated using ergosterol content measurement. To extract the fungi biomass, $20 \mathrm{~mL}$ of $\mathrm{KOH}$ ( $10 \%$ in methanol) were added to $1 \mathrm{~g}$ of fermented solid. The mixture was then agitated with a magnetic stirrer for $30 \mathrm{~min}$ at room temperature. Thereafter, $10 \mathrm{~mL}$ of the mixture was incubated in a bath at $55^{\circ} \mathrm{C}$ for $20 \mathrm{~min}$, left to cool at room temperature, and then, $3 \mathrm{~mL}$ of distilled water and $2 \mathrm{~mL}$ of $n$-hexane were added, and the solution was agitated in a vortex for $1 \mathrm{~min}$. After layers' separation, the upper layer (hexane) was recovered to another flask. This extraction procedure was repeated two more times only using hexane. The extracts were then evaporated with a nitrogen stream and, after $n$-hexane complete evaporation, the dry extracts were dissolved in $2 \mathrm{~mL}$ of methanol. The ergosterol present in this solution was measured using a U-HPLC with UV DAD Shimadzu detector (wave length $282 \mathrm{~nm}$ ). $5 \mu \mathrm{L}$ of sample were injected, and a chromatographic column Kinetex 2,6 Mm 18 100A $(100 \mathrm{~mm} \times 3,0$ $\mathrm{mm}$ ), with a pre-column with the same stationary phase were used. The mobile phase was methanol with a flow of $0.7 \mathrm{~mL} / \mathrm{min}$ and an oven temperature of $30^{\circ} \mathrm{C}$.

\subsection{Enzymatic hydrolysis}

To assess the efficacy of enzymes produced during SSF, at the end of the fermentation process the enzymes produced were extracted, following the method of Salgado et al. (2014). Two different strategies were adopted to carry out the enzymatic hydrolysis (EH; Fig. 1). Strategy 1 (S1) consisted in performing a SSF of both unwashed and washed macroalgae and, after seven days of fermentation, the enzymes produced were extracted and the fermented solids were dried at $55^{\circ} \mathrm{C}$ until constant weight. Then, both dried solids resulted from SSF and the washed macroalgae were hydrolysed using the enzymatic extract obtained from SSF of unwashed U. rigida. Similarly, these substrates were also hydrolysed with a commercial cellulase from Aspergillus niger (Sigma 22178). Both processes were carried out in $1 \mathrm{~L}$ Erlenmeyer flasks with sodium acetate buffer $(\mathrm{pH} 4.6)$ in a ratio solid:liquid 1:5 (w/v) proportion and at $40^{\circ} \mathrm{C}$, for $48 \mathrm{~h}$ and under $130 \mathrm{rpm}$ constant shaking. At the end, the solid was dried at $55{ }^{\circ} \mathrm{C}$ until constant weight and further analysed. 


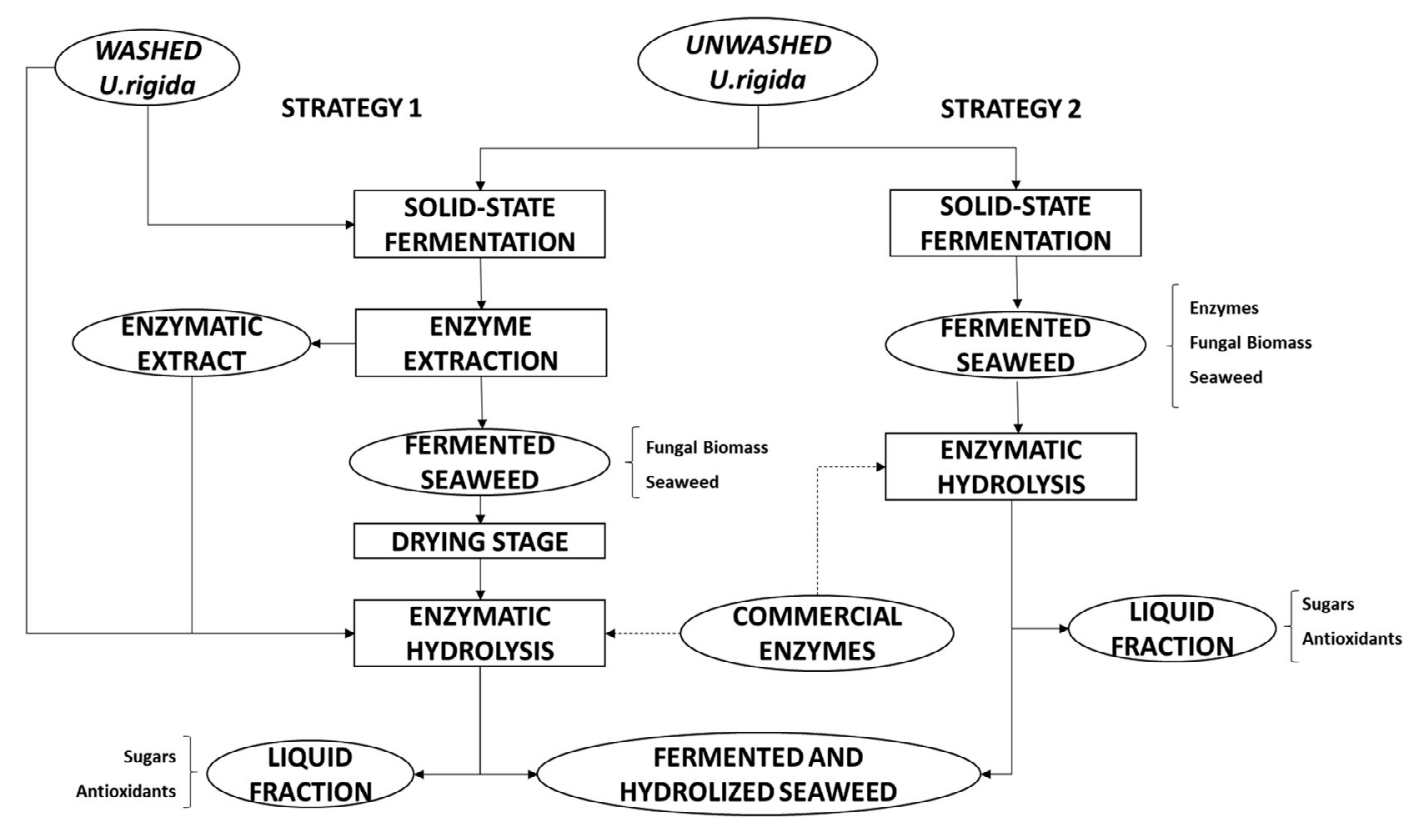

Fig. 1. Flow chart of the two strategies performed to hydrolyze the polysaccharides of $U$. rigida by biological treatments.

The second strategy (S2) differs from the first one because SSF products were not dried and the enzymes produced during SSF were not extracted. Therefore, at the end of SSF process, only sodium acetate buffer ( $\mathrm{pH} 4.6)$ was added to Erlenmeyer flasks in a 1:5 (w/v) proportion. Likewise, in other Erlenmeyer flasks, the same buffer was added but containing the same commercial cellulase as in S1. Thymol was also added as antifungal to avoid the consumption of released sugar during $\mathrm{EH}$. Both $\mathrm{EH}$ were carried out at $40{ }^{\circ} \mathrm{C}$, for $48 \mathrm{~h}$ and under $130 \mathrm{rpm}$ constant shaking.

\subsection{Characterization of untreated and treated U.rigida}

The chemical composition of macroalgae, before and after all biological treatments was evaluated as follows. Total protein content $(\mathrm{N} \times 6.25)$ was determined by the Kjedahl method after digestion with Sulphur acid ( $>95 \%$ ) using a Kjeltec system (Foss 8400). Moisture was determined by drying samples at $105{ }^{\circ} \mathrm{C}$ until constant weight. Salts' content was determined after washing the macroalgae with distilled water for $24 \mathrm{~h}$, followed by slow evaporation at $55^{\circ} \mathrm{C}$ for $24 \mathrm{~h}$ and incineration in a muffle furnace at $505{ }^{\circ} \mathrm{C}$ for $2 \mathrm{~h}$. Total lipids were determined by Soxhlet extraction using petroleum ether as a solvent, at $70{ }^{\circ} \mathrm{C}$ using a FOSS Soxtec 8000 apparatus. Ash content was determined by incineration in a muffle furnace at $505^{\circ} \mathrm{C}$ for $2 \mathrm{~h}$. An extraction with distilled water using a solid:liquid ratio of $1: 5(\mathrm{w} / \mathrm{v})$ was performed to determine free sugars, soluble protein, phenolic content and antioxidant activity. Free reducing sugars were determined by DNS (3,5dinitrosalicylic acid) method (Miller, 1959). Soluble protein was determined by the Bradford method using bovine serum albumin (BSA) as standard (Bradford, 1976). Total phenols content was determined by the Folin-Ciocalteau method, using caffeic acid as a standard (Salgado et al., 2014). Cellulose, hemicellulose and lignin were determined by the method described by Leite et al. (2016).

\subsection{Enzyme activity analysis}

The activities of cellulase, xylanase, and $\beta$-glucosidase were determined in extracts obtained by SSF. After the fermentation period, enzymes were extracted following the method of Salgado et al. (2014). To assess cellulase activity, two different methods were carried out. In method 1, a commercial kit (S-ACMCL; Megazyme International, Ireland), that included endo-1,4- $\beta$-glucanase and AZO-carboxymethyl cellulose as substrate was used, and the reaction was performed at 40 ${ }^{\circ} \mathrm{C}$. In method 2, carboxymethyl cellulose (2\%) in citrate buffer $0.05 \mathrm{~N}$ (pH 4.8) was used as substrate, the reaction was performed at $50{ }^{\circ} \mathrm{C}$ for $30 \mathrm{~min}$, and free sugars were determined by DNS method. In both procedures, one unit of enzyme activity was defined as the quantity of enzyme necessary to release $1 \mu \mathrm{mol}$ of glucose per minute from substrate at the reaction conditions.

Similarly, two methods were also used for the determination of xylanase activity. In method 1 , a commercial kit (Azo Wheat arabinoxylan S-AWAXL 05/14; Megazyme International, Ireland) was used including a specific endo- $1,4-\beta$-xylanase and the reaction temperature was $40^{\circ} \mathrm{C}$. In method 2 , xylan ( $1 \%$ ) in citrate buffer $0.05 \mathrm{~N}$ (pH 4.8) was used, the reaction was incubated at $50{ }^{\circ} \mathrm{C}$ for $15 \mathrm{~min}$, and the released sugars were measured by DNS method. In both methods, one unit of enzyme activity was defined as the quantity of enzyme necessary to release $1 \mu \mathrm{mol}$ per minute of xylose reducing sugar equivalents from the substrate at the reaction conditions.

$\beta$-glucosidase activity was measured following the method described by Leite et al. (2016) and its activity was defined as the amount of enzyme required to release $1 \mu \mathrm{mol}$ per minute of p-nitrofenol. All activities were expressed in activities unit (U) per gram of dry substrate in SSF.

\subsection{Antioxidant activity}

The extracts from untreated and treated macroalgae by biological treatments (from SSF and HE) were obtained as described in Section 2.4. The antioxidant activity was determined using the 2,2-diphenyl-1picrylhydrazyl (DPPH) radical scavenging assay. Known quantities of 6hydroxy-2,5,7,8-tetramethylchroman-2-carboxylic acid (Trolox) were used for calibration. The free radical scavenging activity of the extracts was expressed in millimoles of Trolox equivalent per kilogram of the dry solid substrate $\left(\mathrm{mmol} \mathrm{kg}^{-1}\right)$.

\subsection{Statistical analysis}

All data were analysed by one-way analysis of variance (ANOVA) using the Statgraphics Centurion software. If significant differences were detected $(\mathrm{p}<0.05)$ the Tukey multiple range test was used to discriminate means. 
Table 1

Physicochemical composition of washed and unwashed U. rigida.

\begin{tabular}{|c|c|c|c|}
\hline Parameter & $\begin{array}{l}\text { Unwashed } \\
\text { macroalgae }\end{array}$ & $\begin{array}{l}\text { Washed } \\
\text { macroalgae }\end{array}$ & $\begin{array}{l}\text { Values from } \\
\text { literature }\end{array}$ \\
\hline Humidity $(\% \mathrm{w} / \mathrm{w})$ & $12.2 \pm 0.1^{\mathrm{b}}$ & $11.5 \pm 0.09^{\mathrm{a}}$ & \\
\hline Total solids (\% w/w) & $87.8 \pm 1.8^{\mathrm{a}}$ & $88.5 \pm 0.15^{b}$ & \\
\hline $\mathrm{N}(\% \mathrm{w} / \mathrm{w})$ & $2.7 \pm 0.02^{\mathrm{a}}$ & $3.8 \pm 0.01^{\mathrm{b}}$ & $2.3-5.3$ \\
\hline Salt $(\% \mathrm{w} / \mathrm{w})$ & $22.5 \pm 0.05^{\mathrm{b}}$ & $4.9 \pm 0.02^{\mathrm{a}}$ & \\
\hline Ash (\% w/w) & $43.8 \pm 0.41^{\mathrm{b}}$ & $36.4 \pm 0.7^{\mathrm{a}}$ & $18.4-47.4$ \\
\hline $\begin{array}{l}\text { Crude protein (\% w/ } \\
\text { w) }\end{array}$ & $16.9 \pm 0.07^{\mathrm{a}}$ & $23.6 \pm 0.13^{b}$ & $15.8-33$ \\
\hline Lignin $(\% \mathrm{w} / \mathrm{w})$ & $2.2 \pm 0.01^{\mathrm{a}}$ & $9.8 \pm 0.04^{\mathrm{b}}$ & 1.8 \\
\hline $\begin{array}{l}\text { Hemicellulose (\% w/ } \\
\text { w) }\end{array}$ & $11.7 \pm 0.77^{\mathrm{a}}$ & $12.3 \pm 0.19^{\mathrm{a}}$ & 17.5 \\
\hline Cellulose (\% w/w) & $9.5 \pm 1.39^{\mathrm{a}}$ & $14.0 \pm 0.81^{\mathrm{a}}$ & $13.2-23.8$ \\
\hline Lipids $(\% \mathrm{w} / \mathrm{w})$ & $1.4 \pm 0.01^{\mathrm{a}}$ & $1.7 \pm 0.04^{\mathrm{b}}$ & $0.69-5.4$ \\
\hline Soluble proteins (mg/ & $1.9 \pm 0.14^{\mathrm{b}}$ & $0 \pm 0^{\mathrm{a}}$ & \\
\hline $\begin{array}{c}\left.\mathrm{g}_{\text {dry waste }}\right) \\
\text { Reducing Sugars (mg/ }\end{array}$ & $15.7 \pm 0.03^{b}$ & $6.9 \pm 0.29^{\mathrm{a}}$ & \\
\hline $\begin{array}{l}\text { Phenols (mg/ } \\
\text { gdry waste) }\end{array}$ & $4.51 \pm 0.14^{\mathrm{b}}$ & $1.37 \pm 0.16^{\mathrm{a}}$ & \\
\hline
\end{tabular}

References: (Harchi et al., 2018); (Paiva et al., 2017); (Gao et al., 2017); (Chemodanov et al., 2017); (Korzen et al., 2015).

\section{Results and discussion}

\subsection{Solid-state fermentation of $U$. rigida for lignocellulolytic enzymes production}

The unwashed macroalgae contained a high salt concentration (Table 1), thus it was evaluated as substrate for SSF before and after reduction of salt content by washing. SSF were performed in both macroalgae without nutrients supplementation. In this form, it was studied the effect of salts on the growth of fungus and enzymes production. During the process of washing, it was registered a considerable loss of biomass, mainly salts, free sugars and phenols (Table 1) that were solubilized in the washing process. The characteristics of salts from Ulva sp. are considered healthy for humans due to the high concentration of $\mathrm{K}$ and $\mathrm{Mg}$ (Magnusson et al., 2016). In addition, these minerals are essential for germination of the fungal spores (Senthilkumar et al., 2005), thus the effect of these salts on SSF is an important aspect to consider.

After SSF of washed and unwashed macroalgae, the loss of biomass was $6.7 \%$ and $12.7 \%$, respectively. Fig. 2 a shows the production of xylanases after SSF of unwashed and washed macroalgae by $A$. ibericus. Using the unwashed macroalgae as substrate, higher xylanase activity was obtained than with washed macroalgae, with a significant increase of 1.7-fold for xylanase activity measured with beech wood substrate and 3.8-fold of xylanase activity measured with wheat arabinoxylan substrate. Similar results were obtained for cellulase activity (Fig. 2b), with an endo-1-4- $\beta$-glucanase production 2.2-fold higher with the unwashed macroalgae. However, $\beta$-glucosidase activity was similar in the unwashed and washed macroalgae.

The use of $U$. rigida as substrate for SSF has been scarcely studied. Karray et al. (2016) performed submerged fermentation of $U$. rigida enriched with a nitrogen source to produce cellulase, obtaining lower endo-1-4- $\beta$-glucanase and higher $\beta$-glucosidase activities than in the present study. Trivedi et al. (2015) performed SSF of washed Ulva fasciata supplemented with minerals, and obtained an endo-1-4- $\beta$-glucanase activity of $10.2 \pm 0.4 \mathrm{U} / \mathrm{g}$ with a cellulase-producer strain isolated from decomposed Ulva. This value is close to the endo-1-4- $\beta$ glucanase activity obtained with $A$. ibericus using washed macroalgae $(19.0 \pm 1.6)$, but far lower than the value obtained in the present study using unwashed $U$. rigida $(42.4 \pm 3.6)$. Thus, it may be concluded that washing macroalgae impaired enzymes production by SSF. Such results can be possibly explained by higher quantity of reducing

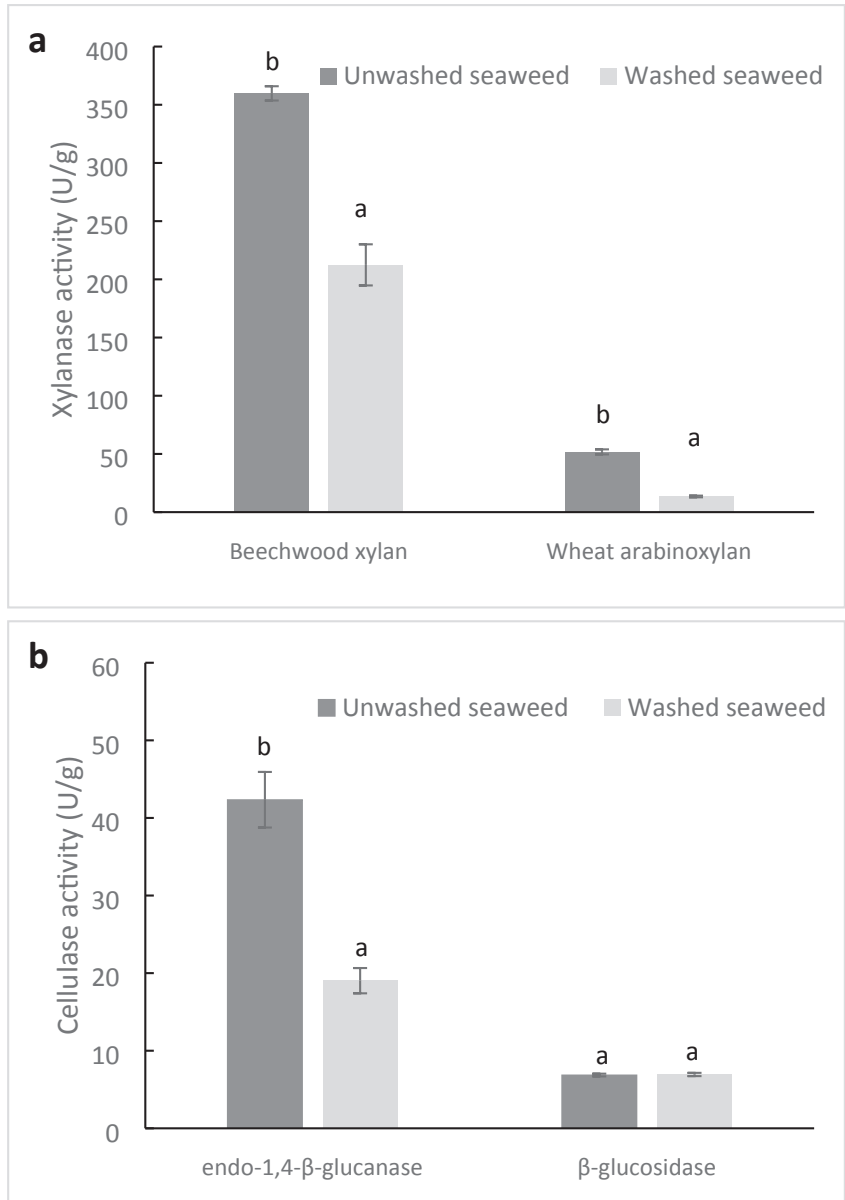

Fig. 2. Production of enzymes by solid-state fermentation of unwashed and washed $U$. rigida. (a) Xylanase activities (endo-1,4- $\beta$-xylanase). (b) endo-1-4- $\beta$ glucanase and $\beta$-glucosidase activities. Letters above each bar indicate the results of Tukey's test $(P<0.05)$; values with shared letters in the same graph are not significantly different.

sugars in the unwashed than in the washed macroalgae, which might help to promote fungi growth and the production of more enzymes (Manan and Webb, 2017). In addition, the wash out of some elements, such as minerals, when the macroalgae was washed with distilled water, probably impoverished the substrate nutritional conditions to support an optimal growth for the fungi (Farinas, 2015). In this sense, a positive effect of mineral salts from macroalgae and from natural seawater on cellulase production by SSF was observed by Xue et al. (2012), being $\mathrm{Na}$ and $\mathrm{Mg}$ the main minerals promoting cellulase production.

Another important factor to consider is the substrate structure, which may also affect fungi growth. After washing, the macroalgae became more rigid and compact than the unwashed macroalga, and this might have hindered $A$. ibericus to successfully penetrate the substrate and access the macroalgae nutrients.

\subsection{Scale-up of enzymes production in tray-type bioreactors}

The production of enzymes by SSF was evaluated in tray-type bioreactor with 2 solids load of 50 and $400 \mathrm{~g}$ of dry solid and it was compared to flask fermentation with $10 \mathrm{~g}$ (Fig. 3a). The height of the bed substrate was similar in the three solids loading $(2-2.5 \mathrm{~cm})$. Xylanase production during the SSF of 10 and $50 \mathrm{~g}$ of dry solid was similar and higher than that obtained with $400 \mathrm{~g}$ of dry solid. $\beta$-glucosidase production attained a maximum activity of $15.5 \pm 0.4 \mathrm{U} / \mathrm{g}$ with the SSF of $50 \mathrm{~g}$ of dry solid, while cellulase production was higher with SSF 


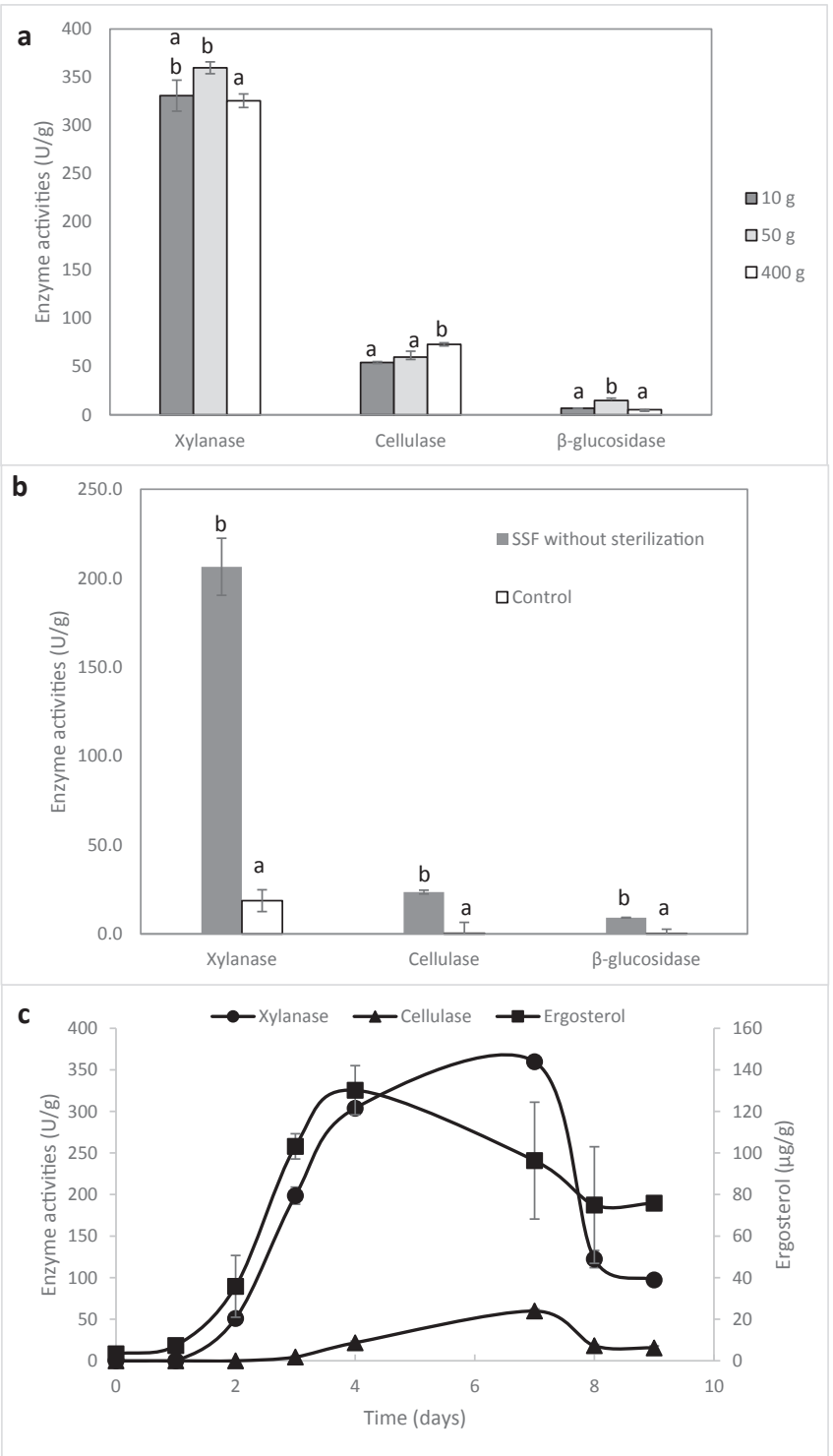

Fig. 3. (a) Production of enzymes by scale-up of SSF on tray type bioreactors. (b) Production of enzymes on tray type bioreactor $(50 \mathrm{~g})$ without sterilization an control without sterilization and inoculation. (c) Kinetics of enzymes production and ergosterol content during SSF in tray-type bioreactor with $50 \mathrm{~g}$ of dry solid. Letters above each bar indicate the results of Tukey's test $(\mathrm{P}<0.05)$; values with shared letters in the same graph are not significantly different.

of $400 \mathrm{~g}$ than with 10 or $50 \mathrm{~g}$ of dry solid. Differences in enzymes production relatively to the quantity of dry macroalgae may be due, at least in part, to the higher aeration, mass and heat transfer in tray bioreactor compared to flasks (Khanahmadi et al., 2018). On the other hand, the increase of solids loading can limit the production of enzymes if the bed height is increased (Oliveira et al., 2018), which was not the case of the experiments of this work, since similar height beds were used in both trays $(2.5 \mathrm{~cm})$ and it was not observed an increase of temperature in the bed during SSF.

The need to sterilize the substrate hinders the scale-up of SSF, therefore it was studied the fermentation of macroalgae in tray type bioreactor without sterilization of substrate. Fig. 3b shows the enzymes activities achieved after SSF without sterilization and SSF without sterilization and inoculation (control). The production of enzymes by native microorganisms of macrocalga (control) was null except for xylanase activity, but with a low production. On the other hand, fermentation without sterilization but inoculated with $A$. ibericus lead to the production of enzymes. However, the production of xylanases, cellulases and b-glucosidases were 43, 61 and 38\% lower than fermentation with a sterilized substrate. This positive effect of substrate sterilization on the production of enzymes may be due, at least in part, to the thermal effect that may have acted as pre-treatment increasing the accessibility to macroalga nutrients and polysaccharides (Krishna et al., 1999).

The fungal growth profile and the enzymes production over time on tray-type bioreactor with $50 \mathrm{~g}$ of dry solid are displayed in Fig. 3c. The fungal biomass, measured indirectly by ergosterol content, increased exponentially between the 1st and 4th day of incubation, decreasing thereafter to a stationary phase by day 8 . Xylanase activity was detected after the 2nd day of fermentation, achieving maximum activity at day 7. Cellulase activity was only detected after 4 days of fermentation, also peaking at day 7. This lag-time of cellulase production may be related to the hemicellulose fraction of macroalgae being more exposed than the cellulose fraction, thus first inducing the production of xylanases and only, after the cellulose fraction becoming more accessible, inducing the production of cellulases. A similar effect was also observed in the production of lignocellulolytic enzymes by SSF of olive mill wastes (Leite et al., 2016).

\subsection{Enzymatic hydrolysis and SSF followed by sequential enzymatic hydrolysis}

The potential of enzymes produced by $A$. ibericus under SSF of unwashed $U$. rigida was evaluated on enzymatic hydrolysis (EH).

Fig. 1 shows the two strategies carried out to hydrolyse the polysaccharides of $U$. rigida. In the first strategy, the enzymes produced during the SSF of unwashed macroalgae were extracted and the fermented solid was dried. This crude enzymatic extract was used to hydrolyse the washed macroalgae, and both fermented unwashed and washed macroalgae. A commercial cellulase from A. niger was also used with these substrates to compare with the crude enzymatic extract obtained from SSF of macroalgae. For the three solids used, the amount of glucose and other sugars released by the enzymatic extract hydrolysis was higher than that of the hydrolysis with the commercial cellulase,

Table 2

Enzymatic hydrolysis of different treatments of macroalgae using crude enzymes from SSF of unwashed $U$. rigida and commercial enzymes.

\begin{tabular}{|c|c|c|c|c|c|}
\hline Experiment & Enzyme extract & $\mathrm{Y}_{\mathrm{Gmax}}(\%)$ & {$[\mathrm{G}](\mathrm{mg} / \mathrm{g})$} & $\mathrm{Y}_{\mathrm{TS} \max }(\%)$ & {$[\mathrm{TS}](\mathrm{mg} / \mathrm{g})$} \\
\hline \multirow[t]{2}{*}{$\mathrm{EH}$ of washed macroalgae } & Crude extract & 48.1 & 88.6 & 25.4 & 88.6 \\
\hline & Commercial extract & 5.0 & 18.4 & 3.0 & 22.4 \\
\hline \multirow[t]{2}{*}{$\mathrm{EH}$ of unwashed fermented macroalgae } & Crude extract & 46.4 & 20.6 & 4.4 & 20.6 \\
\hline & Commercial extract & 18.1 & 13.0 & 9.5 & 26.0 \\
\hline \multirow[t]{2}{*}{$\mathrm{EH}$ of washed fermented macroalgae } & Crude extract & 25.7 & 18.1 & 10.4 & 38.7 \\
\hline & Commercial extract & 20.4 & 9.8 & 5.0 & 9.8 \\
\hline \multirow[t]{2}{*}{ Sequential SSF and EH of macroalgae } & Crude extract & 53.1 & 12.2 & 18.8 & 24.1 \\
\hline & Crude + commercial extract & 97.9 & 89.3 & 50.0 & 116.1 \\
\hline
\end{tabular}

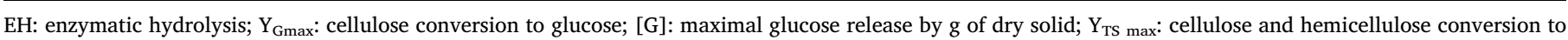
total sugars; [TS]: maximal sugars release by g of dry solid; TS: sum of glucose, rhamnose and galactose. 
except for the $\mathrm{EH}$ of unwashed fermented macroalgae where the release of total sugars by commercial enzyme was slightly higher (Table 2). The highest glucan conversion yield was achieved through the hydrolysis with crude enzymatic extract of washed macroalgae (48\%), followed by the washed and fermented macroalgae (46\%). Thus, no differences were observed between washed macroalgae and macroalgae submitted to the EH. Total sugars conversion was lower because rhamnose and galactose were not released from ulvan fraction of macroalgae. Enzymatic hydrolysis of other Ulva species has also been evaluated. For instance, Parab et al. (2017) achieved maximum glucan conversion yield of $37 \%$ after treating $U$. lactuca with hot water and subsequent hydrolysis by carbohydrases produced by Bacillus strain. On the other hand, Jmel et al. (2018) observed that direct hydrolysis of untreated $U$. lactuca allowed achieving a glucose yield close to $30 \%$ using low solid load, and the release of glucose from macroalgae was further improved by applying other thermal and chemical treatments. However, these pre-treatments are harmful to the environment and high-energy consumers. Further, hydrolysis of $U$. prolifera, using a depolymerase reached $50 \%$ of reducing sugars conversion (Li et al., 2015). Therefore, EH using enzymes obtained from SSF process can efficiently hydrolyse macroalgae without implying environmental risks and high energy requirements.

A different strategy (Strategy 2) was performed to try to improve the conversion of polysaccharides into free sugars. In this case, the enzymes produced during SSF were not extracted and the solid was not dried. Thus, the fermented solid was immediately submitted to sequential hydrolysis with the crude enzymatic extract, after adding thymol to the fermented solid as antifungal to avoid the consumption of released sugars during EH. This strategy allowed reduce several operation stages and to increase the glucose conversion to $53 \%$. As can be observed in Fig. 4a, glucose conversion was improved to $98 \%$ by the addition of commercial extract along with the crude extract produced by SSF. In

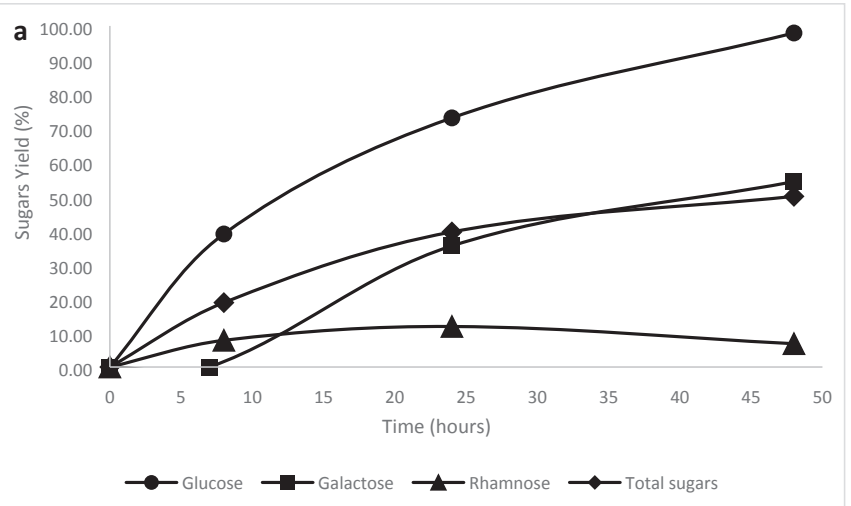

b

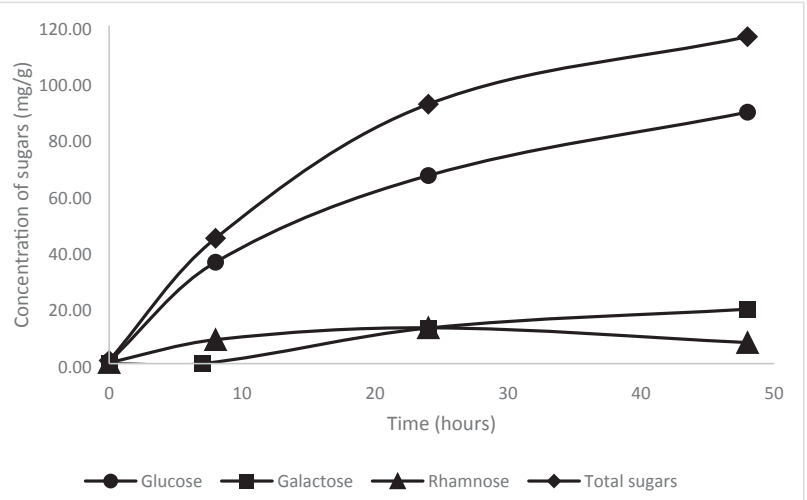

Fig. 4. Reduction of polysaccharides of unwashed $U$. rigida by sequential SSF and enzymatic hydrolysis. (a) Polysaccharides yield conversion. (b) Concentration of sugars released per gram of dried biomass. addition, total sugars conversion was improved after $48 \mathrm{~h}$ of $\mathrm{EH}$, and reached $50 \%$, since the $97.9 \%$ glucose was released along with $54.4 \%$ galactose and $6.8 \%$ rhamnose (Fig. 4a). The quantity of glucose, rhamnose and galactose released after $48 \mathrm{~h}$ of EH was 116.1, 12.7, and $19.3 \mathrm{mg} / \mathrm{g}$, respectively (Table 1, Fig. 4b). A synergistic effect of crude extracts mixture with commercial enzymes was also observed in the hydrolysis of poplar biomass, where the release of sugars was $20 \%$ more efficient than when using only commercial extracts (Celluclast 1.5L and Novozyme 188) (Jagtap et al., 2014). Rhamnose is the main sugar of ulvan fraction (Korzen et al., 2015), and it is necessary the addition of water solutions with low $\mathrm{pH}$ at $80-90{ }^{\circ} \mathrm{C}$ for its extraction (Yaich et al., 2017). Cellulase could improve ulvan extraction, but followed by hot water extraction and using a high load of enzyme $(700 \mathrm{U} / \mathrm{g}$ ) (Yaich et al., 2017). Thus, in the present study, the hydrolysis of rhamnose was low because the insufficient load of enzyme or performance of a suitable pre-treatment.

\subsection{Effects of biological treatments on polysaccharides and protein contents}

SSF of macroalgae induced a biomass loss of about $6.7 \%$ and $12.7 \%$ for washed and unwashed macroalgae, respectively, while SSF followed by sequential HE led to a biomass loss of $58 \%$. This biomass loss was mainly caused by the action of cellulases and xylanases produced by the fungus, which hydrolysed the macroalgae polysaccharides. As can be observed in Fig. 5, during SSF of macroalgae, cellulose was the main polysaccharide hydrolysed by the enzymes. The hemicellulose content was barely reduced during SSF of washed macroalgae, and it seems to be directly related to the low production of xylanases. The SSF of unwashed macroalgae led to the highest total polysaccharides reduction, since it also showed the highest cellulase and xylanase production $\left(54.2 \pm 1.0\right.$ and $330.9 \pm 16.0 \mathrm{Ug}^{-1}$, respectively). The hydrolysis of polysaccharides was even larger after the SSF followed by sequential $\mathrm{EH}$, leading to $90 \%$ of reduction of total polysaccharides.

Protein concentration was enriched after all biological treatments, being maximal through SSF and sequential EH (Table 3). This protein increase seems to be mainly related to the biomass loss due to the action of fungal enzymes over polysaccharides. Taking the biomass loss into account, the higher protein increase was achieved by SSF of unwashed macroalgae $(10.2 \%)$, while by SSF of washed macroalgae protein only increased by $1.7 \%$. The protein content is the main component of $A$. ibericus biomass $(37.1 \%, \mathrm{w} / \mathrm{w})$ which may explain the protein increase of fermented unwashed $U$. rigida. Therefore, $U$. rigida protein content, after SSF, is higher than that of other macroalgae or even higher than some of the most common feedstuffs used in aquafeeds, except fishmeal and soybean meal (Table 3), which may reduce aquafeed cost per gram of protein.

Though bioavailability of macroalgae nutrients may be limited, it was already possible to verify that the enzymatic pre-treatment of macroalgae was effective in increasing 3.2 fold their amino acids

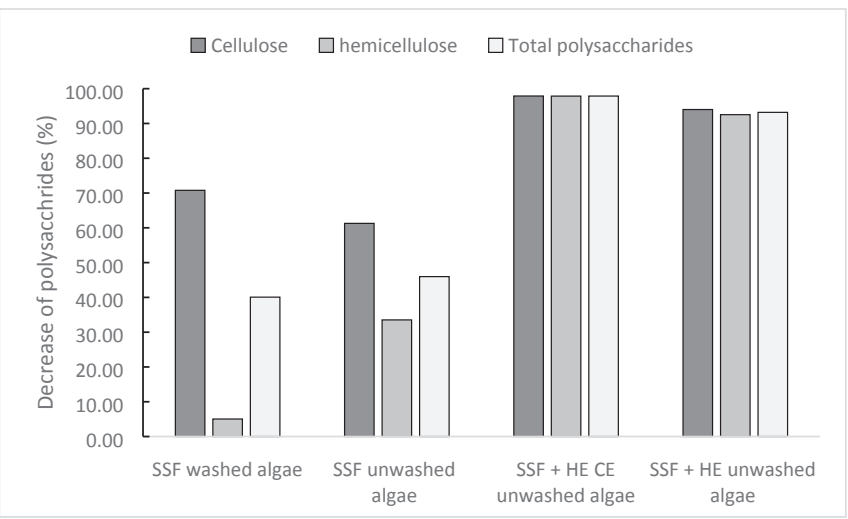

Fig. 5. Decrease of polysaccharides of $U$. rigida after biological pretreatments. 
Table 3

Crude protein content after different biological treatments and comparison with other macroalgae.

\begin{tabular}{|c|c|c|}
\hline Biological treatments of $U$. rigida & Initial Protein (\% DW) & Final Protein (\% DW) \\
\hline SSF of unwashed macroalgae & $16.91 \pm 0.07^{\mathrm{a}}$ & $21.34 \pm 0.26^{\mathrm{b}}$ \\
\hline SSF of washed macroalgae & $23.55 \pm 0.13^{\mathrm{bc}}$ & $25.67 \pm 0.43^{\mathrm{cd}}$ \\
\hline SSF and EH of unwashed macroalgae with crude extract & $16.91 \pm 0.07^{\mathrm{a}}$ & $29.81 \pm 1.19^{\mathrm{e}}$ \\
\hline SSF and EH of unwashed macroalgae with crude and commercial extract & $16.91 \pm 0.07^{\mathrm{a}}$ & $27.8 \pm 0.23^{\mathrm{de}}$ \\
\hline Other sources of protein & Protein (\% DW) & \\
\hline a Alaria esculenta (brown macroalgae) & 9.11 & \\
\hline${ }^{\mathrm{a}}$ Fucus vesiculosus (brown macroalgae) & 6.11 & \\
\hline anteromorpha intestinalis (green macroalgae) & 11.33 & \\
\hline${ }^{\mathrm{a} U l v a}$ lactuca (green macroalgae) & 8.65 & \\
\hline${ }^{a}$ Palmaria palmata (red macroalgae) & 12.26 & \\
\hline${ }^{\mathrm{a}}$ Vertebrata lanosa (red macroalgae) & 11.56 & \\
\hline${ }^{\mathrm{a}}$ Corn meal & 4.11 & \\
\hline Fishmeal & 61.15 & \\
\hline Soybean meal & 43.52 & \\
\hline Whole wheat meal & 13.16 & \\
\hline
\end{tabular}

a (Mæhre et al., 2014); DW: dry weigh.

availability in intestinal absorption (Mæhre et al., 2016). Therefore, we can state that SSF is a viable biotechnological procedure that can be used as a biological treatment prior to the utilization of enzymes or other substances which aim to hydrolyse the cellulose content of $U$. rigida.

\subsection{Effects of biological treatments on the release of antioxidant compounds}

The quantity of phenols in $U$. rigida (Table 4) was higher than measured by Yildiz et al. (2012). This difference may be due to seasonal variation in phenolic compounds of macroalgae. Indeed, Trigui et al. (2013) showed a strong variation of phenolic compounds of $U$. rigida harvested in different months of the year. In the present study, it was observed that washing caused a reduction in phenolic compounds and antioxidant activity of macroalgae. EH increased the phenolic compounds of fermented and unfermented and the antioxidant activity respect to initial raw macroalgae. The highest increase of antioxidant activity and phenolic compounds was achieved by $\mathrm{EH}$ of fermented unwashed macroalgae, following EH performed on dried fermented macroalgae, which increased circa 4-fold and 4.3-fold relatively to the untreated macroalgae. When strategy 2 was used, the increase of antioxidant activity was 2.8 -fold higher than in the untreated macroalgae, and the liberation of phenolic compounds was also higher than untreated macroalgae (1.6-fold).

The increase of antioxidant activity achieved with EH of SSF may be explained by xylanases and cellulases produced by $A$. ibericus that promoted the liberation of phenolic compounds attached to polysaccharides. Indeed, carbohydrate degrading enzymes can release phenolic compounds in conjugated form, thus leading to an increase in antioxidant activity (Dulf et al., 2016). The higher antioxidant after EH compared to SSF may be due to the optimal temperature conditions for the activity of the enzymes. Previously, liberation of phenolic compounds by EH was also observed by Bei et al. (2018).

\subsection{SEM analysis}

SEM analysis allowed observing the surface morphology of macroalgae submitted to the different treatments. Comparing unwashed and washed macroalgae, evidences the effect of washing in reducing salt crystals from macroalgae surface. The SSF of macroalgae also caused alterations on its morphology. In unwashed macroalgae, the surface roughness increased and some cracks appeared, in contrast to unfermented macroalgae that showed a nonporous and smooth surface with salt crystals. Similar changes on green macroalgae structure were previously observed by Jmel et al. (2018) using physical and chemical pre-treatments as organosolv, alkaline and ionic solutions. Fungus growth on unwashed macroalgae was massive over the whole macroalgae surface and as well as inside its substrate, and fungus developed in form of hyphae and conidia. On the other hand, in washed macroalgae fungus mainly presented conidia and low hyphae growth. This could be linked to the low production of enzymes observed in SSF macroalgae, since highly branching hyphae increase cellulases production (He et al., 2016).

For sequential SSF and EH treatment, a massive degradation of macroalgae was observed. The untreated macroalgae showed compact and intact surface with salt crystals while after SSF and HE the surface of macroalgae presented high roughness and many holes. It is known that NSP enzymes action causes undulating surfaces and large quantity of hollow regions (Li et al., 2018). The branching hyphal morphology of the fungus allowed it to colonize all substrate and to release carbohydrase enzymes, which strongly degraded macroalgae polysaccharides during EH. In addition, the degradation produced by enzymes may improve the bioaccessibility of macroalgae proteins (Mæhre et al.,

Table 4

Variation of phenolic compounds and antioxidant activity after biological treatments.

\begin{tabular}{|c|c|c|}
\hline Biological treatments of $U$. rigida & Phenolic compounds $(\mathrm{mg} / \mathrm{g})$ & Antioxidant activity ( $\mu \mathrm{mol}$ Trolox/g) \\
\hline Unwashed macroalgae & $4.51 \pm 0.14^{\mathrm{c}}$ & $2.36 \pm 0.14^{\mathrm{ab}}$ \\
\hline Washed macroalgae & $1.37 \pm 0.16^{\mathrm{a}}$ & $0.84 \pm 0.04^{\mathrm{a}}$ \\
\hline SSF of unwashed macroalgae & $2.99 \pm 0.11^{\mathrm{b}}$ & $1.71 \pm 0.02^{\mathrm{ab}}$ \\
\hline SSF of washed macroalgae & $4.92 \pm 0.62^{\mathrm{c}}$ & $1.66 \pm 0.03^{\mathrm{ab}}$ \\
\hline $\mathrm{EH}$ of washed macroalgae & $16.76 \pm 0.7^{\mathrm{e}}$ & $3.6 \pm 0.45^{\mathrm{bc}}$ \\
\hline EH of SSF of unwashed macroalgae & $20.03 \pm 0.22^{g}$ & $9.5 \pm 0.24^{\mathrm{f}}$ \\
\hline $\mathrm{EH}$ of SSF of washed macroalgae & $18.15 \pm 0.37^{\mathrm{f}}$ & $9.13 \pm 0.17^{\mathrm{ef}}$ \\
\hline SSF and EH of unwashed macroalgae with crude extract & $7.14 \pm 0.15^{\mathrm{d}}$ & $5.24 \pm 0.4^{\mathrm{cd}}$ \\
\hline SSF and EH of unwashed macroalgae with crude and commercial extract & $6.75 \pm 0.33^{\mathrm{d}}$ & $6.7 \pm 2.26^{\mathrm{de}}$ \\
\hline
\end{tabular}

SSF: solid-state fermentation; EH: enzymatic hydrolysis. 
2016).

\subsection{Application to the aquafeed industry}

Aquaculture industry still relies on fish meal (FM) and fish oil (FO) as main protein and lipid sources for carnivorous fish species (Tacon and Metian, 2015). Macroalgae are considered an add-value ingredient due to its content on long-chain polyunsaturated acids, vitamins, minerals, pigments and antioxidant compounds, but its dietary inclusion level may be limited due to the high content of NSP (Wan et al., 2018). Indeed, high dietary level of NSP may affect the viscosity and transit velocity rate of digesta, intestinal morphology, and gut microbiota, impairing the intestinal function (Sinha et al., 2011).

The potential of application of the pre-treatment of $U$. rigida, developed in the present study, was tested with European seabass (Dicentrarchus labrax L.), one of the most important commercial aquaculture species in Europe. The effect of dietary inclusion of untreated and pre-treated $U$. rigida incorporated at $5 \%$ of the diet was evaluated on growth performance, feed utilization, body composition and muscle total phenolic compounds of European seabass. Results of this trial are not aim of the present study and will be presented elsewhere. Briefly the growth performance of fish fed the SSF $U$. rigida based diet was higher than those fed with untreated and enzymatic treated $U$. rigida based diets. Feed efficiency was highest with the SSF- U. rigida based diet than the with the enzymatic treated $U$. rigida diets. However, total muscle polyphenols were higher in fish fed with untreated $U$. rigida based diets. Results indicated promising value of the SSF-treated macroalgae.

Besides the potential of pre-treated $U$. rigida as dietary ingredient, the enzymes produced during macroalgae fermentation may also have high potential of application in the aquafeeds industry. Indeed, it has been observed that dietary supplementation with carbohydrases increases overall feed utilization, by increasing diet digestibility (Diógenes et al., 2018; Magalhães et al., 2016; Zhu et al., 2016). Polysaccharides hydrolysis is important to increase carbohydrate availability for the animal, and to increase accessibility of digestive enzymes to macroalgae protein (Joubert and Fleurence, 2008).

The biological pretreatment of $U$. rigida applied in the present study successfully reduced its polysaccharides content and increased its protein content. Moreover, important carbohydrases were produced during SSF. This represents a step towards the feasibility of $U$. rigida incorporation in aquafeeds as alternative ingredient with functional characteristics, as the enzymes produced during SSF can contribute to enhance feed digestibility. Moreover, the antioxidant content of $U$. rigida may modulate filet quality, by delaying muscle oxidation, increasing filet shelf-time and preserve organoleptic and nutritional traits (Hamre et al., 2004). Furthermore, antioxidants may also be important to reduce fish susceptibility to oxidative stress, promoting physiological homeostasis and decreasing oxidative damages (Aklakur, 2018; Hamre et al., 2004).

\section{Conclusions}

Using $U$. rigida without washing as substrate for cellulases and xylanases production was successful, while washing reduced enzymes production. SSF, without enzymes extraction and drying, followed by EH was the best strategy to hydrolyse macroalgae polysaccharides, increase protein concentration and antioxidant compounds in fermented macroalgae, and to increase macroalgae roughness and degradation, making it more susceptible to fungi' enzymes activity. This pre-treatment increased the potential of $U$. rigida inclusion in aquafeeds, as protein source and functional ingredient, enriched with natural antioxidants and enzymes. Further studies are however necessary to evaluate in vivo the potential of this product as aquafeed ingredient.

\section{Acknowledgements}

Helena Fernandes was supported by PhD grant SFRH/BD/131219/ 2017, funded by the Portuguese Foundation for Science and Technology (FCT).

José Manuel Salgado was supported by grant CEB/N2020 - INV/01/ 2016 from Project "BIOTECNORTE - Underpinning Biotechnology to foster the north of Portugal bioeconomy" (NORTE-01-0145-FEDER000004). This work was supported by the R\&D\&I project "Development of innovative sustainable protein and omega-3 rich feedstuffs for aquafeeds, from local agro-industrial by-products", reference POCI-010145-FEDER-030377, funded by European Regional Development Fund (ERDF) and Portuguese Foundation for Science and Technology (FCT); by the InovFeed project (ref. MAR-02.01.01-FEAMP-0111) supported by Programa Operacional Mar2020, and by the Portuguese Foundation for Science and Technology under the scope of the strategic funding of UID/BIO/04469/2019 and BioTec-Norte operation (NORTE-01-0145FEDER-000004) funded by the European Regional Development Fund under the scope of Norte2020 - Programa Operacional Regional do Norte.

\section{Appendix A. Supplementary data}

Supplementary data (SEM micrographs) to this article can be found online at https://doi.org/10.1016/j.biortech.2019.02.068.

\section{References}

Aklakur, M., 2018. Natural antioxidants from sea: a potential industrial perspective in aquafeed formulation. Rev. Aquac. 10, 385-399. https://doi.org/10.1111/raq. 12167.

Bei, Q., Chen, G., Lu, F., Wu, S., Wu, Z., 2018. Enzymatic action mechanism of phenolic mobilization in oats (Avena sativa $L$.) during solid-state fermentation with Monascus anka. Food Chem. 245, 297-304. https://doi.org/10.1016/j.foodchem.2017.10.086.

Biancarosa, I., Belghit, I., Bruckner, C.G., Liland, N.S., Waagbø, R., Amlund, H., Lock, E., 2018. Chemical characterization of 21 species of marine macroalgae common in Norwegian waters : benefits of and limitations to their potential use in food and feed. https://doi.org/10.1002/jsfa.8798.

Bradford, M.M., 1976. A rapid and sensitive method for the quantification of microgram quantities of protein utilizing the principle of protein-dye binding. Anal. Biochem. 72, 248-254. https://doi.org/10.1016/0003-2697(76)90527-3.

Castillo, S., Gatlin, D.M., 2015. Dietary supplementation of exogenous carbohydrase enzymes in fish nutrition: a review. Aquaculture 435, 286-292. https://doi.org/10. 1016/j.aquaculture.2014.10.011.

Chemodanov, A., Robin, A., Golberg, A., 2017. Bioresource Technology Design of marine macroalgae photobioreactor integrated into building to support seagriculture for biorefinery and bioeconomy. Bioresour. Technol. 241, 1084-1093. https://doi.org/ 10.1016/j.biortech.2017.06.061.

Diógenes, A.F., Castro, C., Carvalho, M., Magalhães, R., Estevão-Rodrigues, T.T., Serra, C.R., Oliva-Teles, A., Peres, H., 2018. Exogenous enzymes supplementation enhances diet digestibility and digestive function and affects intestinal microbiota of turbot (Scophthalmus maximus) juveniles fed distillers' dried grains with solubles (DDGS) based diets. Aquaculture 486, 42-50. https://doi.org/10.1016/j.aquaculture.2017. 12.013.

Dulf, F.V., Vodnar, D.C., Socaciu, C., 2016. Effects of solid-state fermentation with two filamentous fungi on the total phenolic contents, flavonoids, antioxidant activities and lipid fractions of plum fruit (Prunus domestica L.) by-products. Food Chem. 209, 27-36. https://doi.org/10.1016/j.foodchem.2016.04.016.

FAO, 2018. The State of World Fisheries and Aquaculture 2018 - Meeting the sustainable development goals. Rome.

Farinas, C.S., 2015. Developments in solid-state fermentation for the production of biomass-degrading enzymes for the bioenergy sector. Renew. Sust. Energ. Rev. 52, 179-188. https://doi.org/10.1016/j.rser.2015.07.092.

Gao, G., Clare, A.S., Rose, C., Caldwell, G.S., 2017. Reproductive sterility increases the capacity to exploit the green seaweed Ulva rigida for commercial applications. Algal Res. 24, 64-71. https://doi.org/10.1016/j.algal.2017.03.008.

Hamre, K., Christiansen, R., Waagbø, R., Maage, A., Torstensen, B.E., Lygren, B., Lie, Wathne, E., Albrektsen, S., 2004. Antioxidant vitamins, minerals and lipid levels in diets for Atlantic salmon (Salmo salar, L.): effects on growth performance and fillet quality. Aquac. Nutr. 10, 113-123. https://doi.org/10.1111/j.1365-2095.2003. 00288.x.

Harchi, M. El, Kachkach, F.Z.F., Mtili, N. El, 2018. South African Journal of Botany Optimization of thermal acid hydrolysis for bioethanol production from Ulva rigida with yeast Pachysolen tannophilus. South African J. Bot. 115, 161-169. https://doi. org /10.1016/j.sajb.2018.01.021.

He, R., Li, C., Ma, L., Zhang, D., Chen, S., 2016. Effect of highly branched hyphal morphology on the enhanced production of cellulase in Trichoderma reesei DES-15. 3. 
Biotech 6, 1-10. https://doi.org/10.1007/s13205-016-0516-5.

Ilias, N.N., Jamal, P., Jaswir, I., Sulaiman, S., Zainudin, Z., Azmi, A.S., 2015. Potentiality of selected seaweed for the production of nutritious fish feed using solid state fermentation. J. Eng. Sci. Technol. 10, 30-40.

Jagtap, S.S., Dhiman, S.S., Kim, T., Kim, I., Lee, J., 2014. Characterization of a novel endo- $\beta$-1, 4-glucanase from Armillaria gemina and its application in biomass hydrolysis 661-669. https://doi.org/10.1007/s00253-013-4894-x.

James, R.A., Vignesh, S., Subramanian, V., 2012. Marine drugs development and social implication. Coastal Environments: Focus on Asian Regions 219-237. https://doi. org/10.1007/978-90-481-3002-3.

Appl. Biochem. Biotechnol. 184 (3), 777-793. https://doi.org/10.1007/s12010-0172588-Z.

Joubert, Y., Fleurence, J., 2008. Simultaneous extraction of proteins and DNA by an enzymatic treatment of the cell wall of Palmaria palmata (Rhodophyta). J. Appl. Phycol. 20, 55-61. https://doi.org/10.1007/s10811-007-9180-9.

Karray, R., Hamza, M., Sayadi, S., 2016. Bioresource Technology Production and characterization of enzymatic cocktail produced by Aspergillus niger using green macroalgae as nitrogen source and its application in the pre-treatment for biogas production from Ulva rigida. Bioresour. Technol. 216, 622-628. https://doi.org/10. 1016/j.biortech.2016.05.067.

Khanahmadi, M., Arezi, I., Amiri, M.S., Miranzadeh, M., 2018. Bioprocessing of agroindustrial residues for optimization of xylanase production by solid- state fermentation in flask and tray bioreactor. Biocatal. Agric. Biotechnol. 13, 272-282. https:// doi.org/10.1016/j.bcab.2018.01.005.

Korzen, L., Pulidindi, N., Israel, A., 2015. RSC Advances Single step production of bioethanol from the seaweed Ulva rigida using sonication $\uparrow$. RSC Adv. 5, 16223-16229. https://doi.org/10.1039/C4RA14880K.

Kostas, E.T., White, D.A., Cook, D.J., 2017. Development of a bio-refinery process for the production of speciality chemical, biofuel and bioactive compounds from Laminaria digitata. Algal Res. 28, 211-219.

Krishna, C., 1999. Production of bacterial cellulases by solid state bioprocessing of banana wastes. Bioresour. Technol. 69 (3), 231-239.

Leite, P., Salgado, J.M., Venâncio, A., Domínguez, J.M., Belo, I., 2016. Ultrasounds pretreatment of olive pomace to improve xylanase and cellulase production by solidstate fermentation. Bioresour. Technol. 214, 737-746. https://doi.org/10.1016/j. biortech.2016.05.028.

Li, J., Yuan, X., Dong, Z., Mugabe, W., Shao, T., 2018. Bioresource Technology The effects of fi brolytic enzymes, cellulolytic fungi and bacteria on the fermentation characteristics, structural carbohydrates degradation, and enzymatic conversion yields of Pennisetum sinese silage. Bioresour. Technol. 264, 123-130. https://doi.org/10. 1016/j.biortech.2018.05.059.

Li, Y., Huang, Z., Qiao, L., Gao, Y., Guan, H., Hwang, H., Aker, W.G., Wang, P., 2015. Purification and characterization of a novel enzyme produced by Catenovulum sp. LP and its application in the pre-treatment to Ulva prolifera for bio-ethanol production. Process Biochem. 50, 799-806. https://doi.org/10.1016/j.procbio.2015.02.013.

Mæhre, H.K., Jensen, I., Eilertsen, K.E., 2016. Enzymatic Pre-Treatment Increases the Protein bioaccessibility and extractability in Dulse (Palmaria palmata). Mar. Drugs 14, 1-10. https://doi.org/10.3390/md14110196.

Mæhre, H.K., Malde, M.K., Eilertsen, K., Elvevoll, E.O., 2014. Characterization of protein, lipid and mineral contents in common Norwegian seaweeds and evaluation of their potential as food and feed. J. Sci. Food Agri. 94, 3281-3290. https://doi.org/10. $1002 / j s f a .6681$.

Magalhães, R., Lopes, T., Martins, N., Díaz-Rosales, P., Couto, A., Pousão-Ferreira, P., Oliva-Teles, A., Peres, H., 2016. Carbohydrases supplementation increased nutrient utilization in white seabream (Diplodus sargus) juveniles fed high soybean meal diets. Aquaculture 463, 43-50. https://doi.org/10.1016/j.aquaculture.2016.05.019.

Magnusson, M., Carl, C., Mata, L., Nys, R. De, Paul, N.A., 2016. Seaweed salt from Ulva : A novel fi rst step in a cascading biore fi nery model 16, 308-316. https://doi.org/10. 1016/j.algal.2016.03.018.

Manan, A.M., Webb, C., 2017. Modern microbial solid state fermentation technology for future biorefineries for the production of added-value products. Biofuel Res. J. 4 , 730-740. https://doi.org/10.18331/BRJ2017.4.4.5.
Miller, G.L., 1959. Use of Dinitrosaliculic Acid Reagemt for Determination of reducing sugar. Anal. Chem. 3, 426-428. https://doi.org/10.1021/ac60147a030.

Miranda, M., Lopez-Alonso, M., García-Vaquero, M., 2017. Macroalgae for functional feed development: applications in aquaculture, ruminant and swine feed industries. Seaweeds: Biodiversity, Environmental Chemistry and Ecological Impacts 133-154.

Oliveira, F., Salgado, M., Pérez-rodríguez, N., Domínguez, J.M., Belo, I., 2018. Lipase production by solid-state fermentation of olive pomace in tray-type and pressurized bioreactors. https://doi.org/10.1002/jctb.5492.

Özçimen, D., İnan, B., 2015. An Overview of Bioethanol Production From Algae 2013.

Paiva, L., Lima, E., Neto, A.I., Marcone, M., 2017. Nutritional and Functional Bioactivity value of selected azorean macroalgae: Ulva compressa, capillacea 82 . https://doi. org/10.1111/1750-3841.13778.

Parab, P., Khandeparker, R., Amberkar, U., Khodse, V., 2017. Enzymatic saccharification of seaweeds into fermentable sugars by xylanase from marine Bacillus sp. strain BT21. 3. Biotech 7, 1-7. https://doi.org/10.1007/s13205-017-0921-4.

Raveendran, S., Parameswaran, B., Ummalyma, S.B., Abraham, A., Mathew, A.K., Madhavan, A., Rebello, S., Pandey, A., 2018. Applications of microbial enzymes in food industry. Food Technol. Biotechnol. 56 (1), 16-30. https://doi.org/10.17113/ ftb.56.01.18.5491.

Salgado, J.M., Abrunhosa, L., Venâncio, A., Domínguez, J.M., Belo, I., 2014. Screening of winery and olive mill wastes for lignocellulolytic enzyme production from Aspergillus species by solid-state fermentation. Biomass Convers. Biorefinery. https://doi.org/10.1007/s13399-013-0100-8.

Senthilkumar, S.R., Ashokkumar, B., Raj, K.C., Gunasekaran, P., 2005. Optimization of medium composition for alkali-stable xylanase production by Aspergillus fischeri Fxn 1 in solid-state fermentation using central composite rotary design 96, 1380-1386. https://doi.org/10.1016/j.biortech.2004.11.005.

Sinha, A.K., Kumar, V., Makkar, H.P.S., Boeck, G. De, Becker, K., 2011. Non-starch polysaccharides and their role in fish nutrition - a review. Food Chem. 127, 1409-1426. https://doi.org/10.1016/j.foodchem.2011.02.042.

Soccol, C.R., Costa, E.S.F. da, Letti, L.A.J., Karp, S.G., Woiciechowski, A.L., Vandenberghe, L.P. de S., 2017. Recent developments and innovations in solid state fermentation. Biotechnol. Res. Innov. 1, 52-71. https://doi.org/10.1016/j.biori. 2017.01.002.

Tacon, A., Metian, M., 2015. Feed Matters: Satisfying the Feed Demand of Aquaculture. Rev. Fish. Sci. Aquac. 23, 1-10. https://doi.org/10.1080/23308249.2014.987209.

Int. J. Food Properties 15 (6), 1182-1189. https://doi.org/10.1080/10942912.2010. 517341.

Trigui, M., Gasmi, L., Zouari, I., 2013. Seasonal variation in phenolic composition, antibacterial and antioxidant activities of Ulva rigida (Chlorophyta) and assessment of antiacetylcholinesterase potential. J. Appl. Phycol. 25, 319-328. https://doi.org/10. 1007/s10811-012-9866-5.

Trivedi, N., Reddy, C.R.K., Radulovich, R., Jha, B., 2015. Solid state fermentation (SSF) derived cellulase for saccharification of the green seaweed Ulva for bioethanol production. Alga Res. 9, 48-54. https://doi.org/10.1016/j.algal.2015.02.025.

Wan, A.H.L., Davies, S.J., Soler-Vila, A., Fitzgerald, R., Johnson, M.P., 2018. Macroalgae as a sustainable aquafeed ingredient. Rev. Aquac. 1-35. https://doi.org/10.1111/raq 12241.

White, W.L., Wilson, P., 2015. World seaweed utilization, Seaweed Sustainability. Elsevier Inc. https://doi.org/10.1016/B978-0-12-418697-2/00002-7.

Appl. Biochem. Biotechnol. 167 (7), 1963-1972. https://doi.org/10.1007/s12010-012 9734-4.

Yaich, H., Ben, A., Abbes, F., Bouaziz, M., Besbes, S., Richel, A., Blecker, C., Attia, H., Garna, H., 2017. International Journal of Biological Macromolecules Effect of extraction procedures on structural, thermal and antioxidant properties of ulvan from Ulva lactuca collected in Monastir coast. Int. J. Biol. Macromol. 105, 1430-1439. https://doi.org/10.1016/j.ijbiomac.2017.07.141.

Zhu, D., Wen, X., Li, S., Xuan, X., Li, Y., 2016. Effects of exogenous non-starch polysaccharide-degrading enzymes in diets containing Gracilaria lemaneiformis on whitespotted snapper Lutjanus stellatus Akazaki. Aquac. Int. 24, 491-502. https://doi.org/ 10.1007/s10499-015-9940-5. 